\title{
Tax Impact on Household Income
}

\author{
Mariyana Pavlova \\ Tsenov Academy of Economics
}

\begin{abstract}
The household income is an important economic indicator because it determines the scale of the household sector consumption and its delay in future in terms of saving and investing. Many factors influence the magnitude of household income and one of these factors is taxation. Given the significance of tax payments not only for household income, and through them - for the national economy, the object of the current study is the household income and in particular the impact of the taxation framework on the formation of disposable income. The aim of the study is to examine the changes in the monetary income of households in the Republic of Bulgaria as a function of the implemented tax reforms in the period following the country's accession to the $E U$.
\end{abstract}

Keywords - Household, income, tax relief, taxes.

\section{INTRODUCTION}

The significance of households to the national economy is indisputable in view of the fact that they are involved in the production of goods and services by providing labour resources, but also they are consumers of goods and services, net savers, according to the magnitude of the disposable income and taxpayers (King, 2014, pp. 15-24). In this sense, each household as a socio-economic category or their totality, forming the household sector, contributes to the economic growth in at least three directions through: high labour productivity of its members, large-scale consumption, and- an increased investment activity (Callaghan, 2007, pp. 47-87). In this case, the disposable household income and its magnitude are important. On the one hand, it is a function of socioeconomic conditions in the country and particularly the tax and social insurance burden (Boskin, 1978, pp. 3-27). On the other hand, it determines the demand for goods and services and postponing consumption into the future - saving and investment activity (Brusarski, 2015, pp. 79-89). In this sense, the tax impact on household income is a theme with a distinct applied science character in view of its importance for personal opportunities in terms of consumption, savings and investments, and, therefore, for the economic activity in the country, given the fact that the household sector is the largest net saver in the national economy. In this regard, the object of the current study is the household income and in particular the impact of the taxation framework on the formation of disposable income. The aim of the study is to examine the changes in the monetary income of households in the Republic of Bulgaria as a function of the implemented tax reforms in the period following the country's accession to the EU.
The hypothesis that the author defends is as follows: "The impact of the tax regulatory framework on household income in the Republic of Bulgaria is an objective reality, which reveals many options for achieving social effects consisting in statutory increase in disposable income of taxpayers and their households." For achieving the intended aim and defending the hypothesis, the author specifies the following tasks:

- to present the structure and the content of the personal monetary income and to clarify the procedure for the formation of the disposable income;

- to examine the dynamics of monetary income of households in the Republic of Bulgaria during the period of 2007-2014, together with the costs for taxes and to derive trends in this regard;

- to clarify aspects of tax impact on the disposable income of households in retrospect and to outline current opportunities for expansion of disposable income through tax relief and preferences specified in the national legislation.

In the methodical aspect, the study is based on the use and application of dynamic and structural analysis, graphic method, as well as methods of description, critical analysis and synthesis.

\section{GENERAL REGULATIONS}

Household incomes are generated from various sources: wages and salaries and other labour (non-labour) remunerations; an investment activity incl. incomes from purchase and sale of items of personal wealth, rents, interests, dividends; an entrepreneurial activity; state social transfers; transfers from persons working abroad; other incomes (Radulova, 2011, pp. 59-64; Rosefsky, 1999, pp. 617-636). The variety of options in the formation of personal monetary inflows allows for their classification into four groups (see Fig. 1).

Expending labour against payment is a preferred and reliable source of incomes which accounts for $2 / 3$ of the available funds of households in Bulgaria (see Table I). Apart from salaries, various fees for services and entrepreneurial income realised by individuals are also referred to this group of monetary inflows (Radulova, 2015, pp. 18-20). As a revenue source in the budgets of Bulgarian households, there are social transfers by the state, such as pensions for length of service or age; compensations for temporary labour disability, unemployment, maternity allowance; grants in cash, because of low social status, scholarships for pupils and students. 


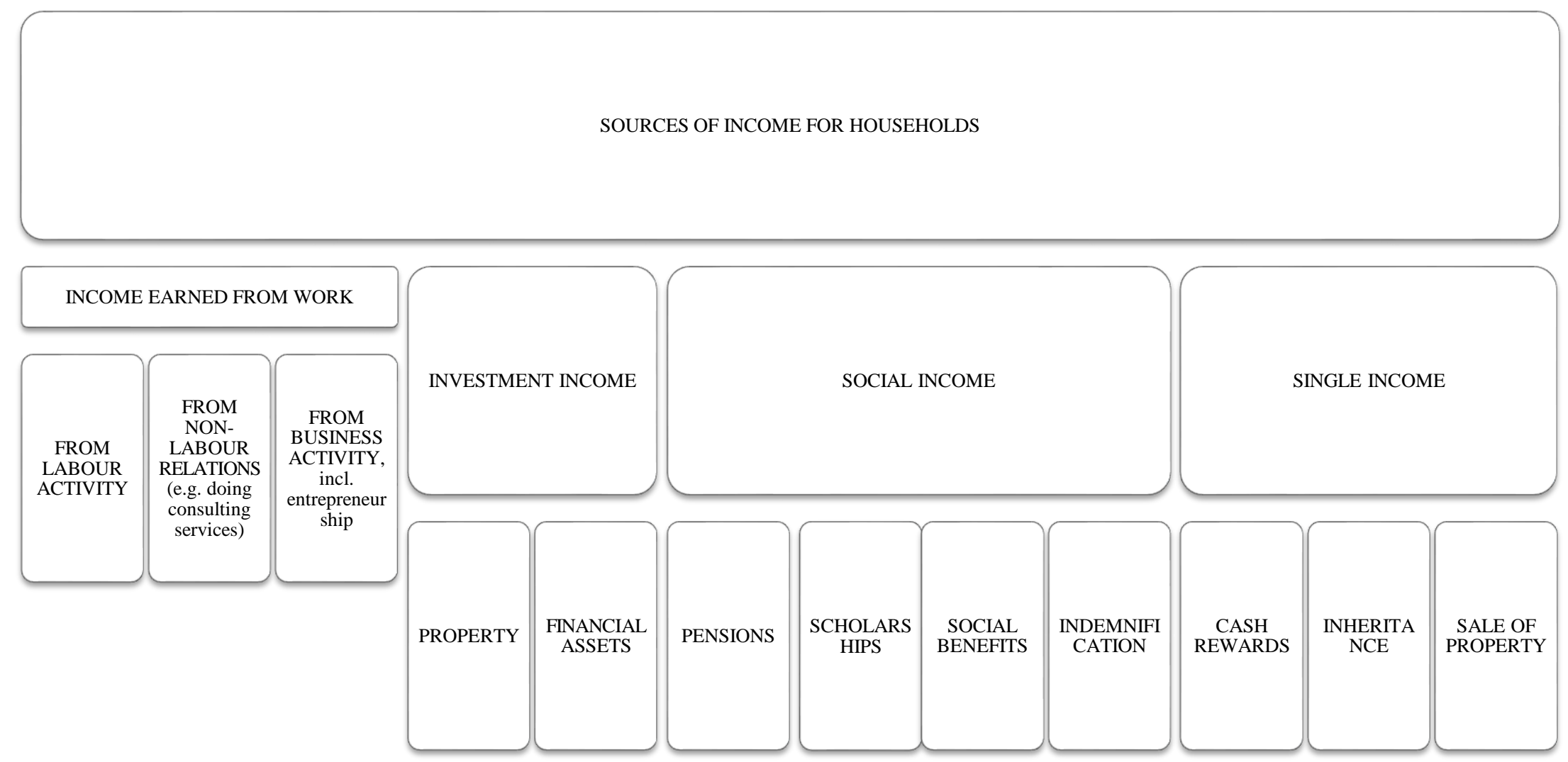

Fig. 1. Sources of income for households. 
The majority of the transfers above are conditionally gratuitous (as at the time of their receipt individuals do not pay the social service but the mandatory requirement to benefit from it is their positive social insurance status) and nontaxable sources of income (Personal Income Tax Act, 2015; Law on State Social Insurance, 2015). Social aid and scholarships for pupils and students are strictly targeted, absolutely gratuitous and also with tax-free nature

Monetary inflows for households can also be formed by the rent, lease, dividends, interest, etc. (Kapoor, 2010, p. 83). The latter are a function of investments made in the past, which at present provide the realisation of passive income (Dimitrova, 2012, pp. 20-38). One-off or exceptional incomes are the least significant (and on recommendation for their use) for households. They, themselves, cannot ensure stable revenue receipt because they arise accidentally as a result of winning a prize, receiving donation, inheritance, sale of property or financial instrument.

It should be noted that a significant part of the abovementioned incomes do not remain at the disposal of households in their full size and they are reduced by the amount of paid taxes and social contributions forming their disposable income on a monthly or annual basis. The Personal Income Tax Act stated twenty-seven non-taxable sources of income, the most important of which are:

- income acquired by a taxable person during the tax year from the sale or exchange of property under certain conditions;

- income from compulsory social insurance and from supplementary voluntary social insurance;

- income from social assistance allowances and benefits, scholarships for studying in Bulgaria and abroad;

- income derived from ground rent, rent charge or from other onerous provision for use of agricultural land;

- any income accruing from the sale or exchange of any property acquired by legal or testamentary succession;

- the amounts received for business travelling and accommodation allowances;

- the remuneration of the members of the staff of diplomatic missions in accordance with Vienna Convention on diplomatic relationships.

All incomes that are not indicated under Art. 13 of the Personal Income Tax Act are subject to a tax rate that is fixed depending on the type of income and varies in the range of $7 \%-15 \%$. The table presented bellow systematises the monetary income of households in Bulgaria in components according to the classification of the National Statistical Institute and tax payments in nominal and relative values during the years after the country's accession to the EU.

The analysis of the information from Table I below shows that since the adoption of the Republic of Bulgaria as a full member of the European Union until 2014 the average disposable income of households increased by more than $60 \%$, while in 2007 it was BGN 7130 and in 2014 it reached to BGN 11 489. The most essential factors are changes in salary, entrepreneurship and pension income, which are the main sources of income for the sector (Dimitrova, 2010, pp. 80-82). On an annual basis, the growth rate of components of monetary income is unstable (and in some cases, it is negative), which is due to the nature of the dynamics of the average monetary income per household. In 2008, the latter grew against the previous year by $17 \%$ - the highest value measured for the study period. Significant growth rate was observed in 2012 and 2013 - respectively $10 \%$ and $12 \%$, while the lowest was in $2010-0.2 \%$.

The nominal amount of tax payments also registered growth: while in 2007 households paid on average BGN 210, in 2014 the obligations reached BGN 403 per year. Reasons are changes in the technology of taxation, increased tax rates and an increase in income. The tax burden, measured by the ratio between the average monetary income of a household and the magnitude of tax payments, remained relatively constant: $2.9 \%$ at the beginning of the studied period and $4.5 \%$ at its end, and the highest value was reached in 2011 when $4.7 \%$ of household income was directed to the state or municipalities in the form of taxes, social security contributions and fees.

Given the characteristic of the structure of monetary household income in the Republic of Bulgaria, the possibility of tax impact on that income and its manifestation are determined. The tax system of our country consists of fifteen duties, a part of which is directed to the state budget and the rest - to the local budgets (Pavlova, 2014, pp. 115-120). In accordance with the objective of the present study, the taxes that affect the disposable income of households must be outlined, namely: taxes on personal income and social security contributions and in certain cases: patent tax; tax on property acquisition by donation; inheritance tax; tax on vehicles; tax on real estate as far as such obligations have the nature of oneoff costs during the year which reduce the disposable income with the magnitude of tax obligation (Local Taxes and Fees Act, 2015). It should be noted that there is a possibility that some of the taxes are paid not at once but at two or four installments during the year. In this sense, the tax impact on households is manifested in two ways: directly, when the object of taxation is the personal income in its various dimensions, or indirectly, when the object of taxation is the individual elements of personal wealth (for instance, a real estate, an automobile, hotchpot), which are dutiable and generating tax liability and cost of its repayment. It should be noted that certain sources of income in our country (pensions, family allowances, unemployment benefits, social benefits) are not dutiable and if the households form the revenue part of the budget only through similar income, practically there is no possibility of direct tax impact. This also applies to the indirect impact when the personal wealth does not include items, which are subject to taxation. Along with the manifestation, the direction of tax impact (positive or negative in terms of personal income) is also of fundamental importance for the finances of households (Angelov, 2010, pp. 43-83). 
TABLE I

MONETARY INCOME AND TAX EXPENDITURE OF HOUSEHOLDS IN THE REPUBLIC OF Bulgaria (AVERAGE VALUES)

\begin{tabular}{|c|c|c|c|c|c|c|c|c|}
\hline Monetary income by years & 2007 & 2008 & 2009 & 2010 & 2011 & 2012 & 2013 & 2014 \\
\hline Total monetary income & 7130 & 8353 & 8807 & 8826 & 9086 & 10037 & 11224 & 11489 \\
\hline Wages and salaries & 3732 & 4505 & 4762 & 4592 & 4793 & 5399 & 6067 & 6327 \\
\hline Other earnings & 359 & 433 & 382 & 198 & 126 & 271 & 436 & 406 \\
\hline Entrepreneurship & 428 & 441 & 434 & 429 & 590 & 650 & 649 & 758 \\
\hline Property income & 76 & 77 & 59 & 69 & 61 & 96 & 124 & 93 \\
\hline Unemployment benefits & 24 & 17 & 50 & 57 & 65 & 67 & 76 & 64 \\
\hline Pensions & 1724 & 2011 & 2519 & 2791 & 2789 & 2730 & 2915 & 3010 \\
\hline Family allowances & 42 & 57 & 84 & 81 & 78 & 84 & 85 & 103 \\
\hline Other social benefits & 188 & 263 & 159 & 161 & 156 & 186 & 169 & 248 \\
\hline Household plot & 108 & 103 & 66 & 50 & 47 & 47 & 54 & 49 \\
\hline Property sale & 126 & 88 & 12 & 37 & 10 & 37 & 76 & 29 \\
\hline Other incomes & 323 & 358 & 280 & 361 & 372 & 470 & 574 & 403 \\
\hline Tax payments & 210 & 260 & 266 & 308 & 446 & 484 & 532 & 545 \\
\hline Monetary income before tax payments & 7340 & 8613 & 9073 & 9134 & 9532 & 10521 & 11756 & 12034 \\
\hline Share of tax payments in monetary income & $2.9 \%$ & $3.0 \%$ & $2.9 \%$ & $3.4 \%$ & $4.7 \%$ & $4.6 \%$ & $4.5 \%$ & $4.5 \%$ \\
\hline
\end{tabular}

Source: NSI

The peculiarity of Bulgarian tax legislation and opportunities for tax relief and preferences have relation to the case. The tax framework in each country, including the Republic of Bulgaria, is subject to a constant change. After the country's accession to the EU, reforms are aimed at harmonisation with European standards, improvement and optimisation of tax system, the most important are:

First: In 2007, the non-taxable minimum at the combined tax progression was increased from BGN 180 to BGN 200, in the reserved upper and lower limit at the other levels of the progression. Tax reliefs for children were also increased, which had a positive influence on the household disposable income.

Second: In 2007 certain changes occurred in tax legislation, concerning taxation of components of household wealth: tax assessments of real estate and vehicle tax were increased.

Third: In 2008, one of the most important changes concerned again the taxation of personal income: the progressive taxation was replaced with proportional taxation with a flat rate of $10 \%$ on all incomes, regardless of their size, removing the existing tax-free threshold and the right to use tax relief for children. The reform aims at increasing of the disposable monetary fund of employees who receive higher income and respectively increasing of household savings. Positive effects on income of the "Households" sector were contradictory, but the new mechanism of taxation reported positive effects on the state treasury: revenues from the taxation of personal income in 2008 marked a 9 per cent increase in comparison with 2007 and the cause of this could be explained by removing of non-taxable minimum.

Fourth: In 2008 the burden of social security contributions between an employee and employer was changed from $35: 65$ to $40: 60$. This strengthens the role of the employee in ensuring means to insurance funds, negatively affecting the household disposable income.

Fifth: In 2010 the changes affected the tax treatment of farmers and tobacco producers' income - inclusiveness of taxation related to incomes of individuals, sole traders producing unprocessed plant and animal products, in a different way of taxation of individuals and sole traders.

Sixth: In 2011, there were also changes, which affected state expenditure for social security, assistance and welfare (one-off allowances paid under certain conditions). There was also a reorganisation of the taxation of rental income by $10 \%$ of normative costs.

Seventh: In 2013, a new tax was introduced, which affected income from investment activities as individuals' deposits the latter were taxed at the rate of $10 \%$. It should be noted that the tax does not cover the expected fiscal revenues. As a result, after a year of its introduction the rate began to decline by $2 \%$ to reach zero per cent in 2017 .

Eighth: Excluding the possibility of tax relief on income not exceeding the minimum salary (BGN 4080 per year), in 2014 changes in tax legislation affecting the income and wealth of the "Household" sector were not essential.

The review of the main changes in the regulatory framework affecting the income and wealth of households in Bulgaria for the period of 2007-2014 gives the opportunity to summarise that the first half of the period is characterised by a greater density of significant taxation events than the second half because of the need for fiscal harmonisation between the Bulgarian and European legislation after the accession of Bulgaria to the European Union. Replacing the Progressive Income Tax with a Flat Tax and reallocating in the burden of social security contributions between the worker and employer can be determined as the most significant events. 
Practical implementation of the outlined methods of tax effects requires a high level of financial awareness by households who should know the actual opportunities for legal increasing of the disposable income through tax relief and preferences.

In 2015, direct tax impact on household income and wealth was achieved through adjustments made in the Personal Income Tax Act, Local Taxes and Fees Act, Tax-Insurance Procedure Code, Social Security Code, most substantial of which are:

- Repeal of tax relief on income from employment, not exceeding the minimum salary.

- New tax relief for children. According to Article 22b from the Personal Income Tax Act, the amount of the annual tax bases on income from employment, business, rent, transfer of rights or property and other sources of local natural persons, meeting certain requirements, shall be reduced by: BGN 200 for one minor child, BGN 400 for two minor children and BGN 600 for three or more minor children. The purpose of this tax relief is an increase of the disposable income of households bringing up children.

- New tax relief for children with disabilities. According to Article $22 \mathrm{~d}$ of the Personal Income Tax Act, the amount of annual tax bases of the above-mentioned sources of income of natural persons shall be reduced by BGN 2000 for bringing a child up by 50 and more than 50 per cent of type and degree of injury. The relief has social purpose given costs for bringing up such a child.

- Expanding the tax base for tax on income of interest, which already includes the gross amount of interest income acquired by local individuals not only on deposits but also on all bank accounts at a tax rate of $8 \%$.

- Tax exemption of interest on bonds or other debt securities issued by the state or the municipalities to certain persons and in specific cases (Personal Income Tax Act, amend. SG 22/24 March 2015 Art. 37(1), paragraph 3).

- Individuals may choose between the advanced withholding of tax on income under Art. 43, paragraph 4 and Art. 44, paragraph 4 , acquired in the fourth quarter of the year and their annual taxation.

- In 2015, the Local Taxes and Fees Act widened the inclusiveness of electric vehicles - except electric cars and electric motorcycles and mopeds. Starting from 2016 a new mechanism will be introduced for determining the household waste fee, which has an impact on budgets of certain households.

- It should be noted that in the Law on State Social Insurance in 2015 the minimum insurance income on main economic activities and qualification groups of professions, and the maximum insurable income were changed from BGN 2400 to BGN 2600 (Appendix No. 1 to Art. 8, paragraph. 1, item. 1 of the Law on State Social Insurance), which indirectly, through required social security contributions at the expense of people working under employment, certain non-labour relations and selfemployed, affect the disposable income of specific households.
- Along with the above-mentioned changes, the existing until 2015 opportunities for tax relief on behalf of individuals also retained. As a result of these changes and possibilities, the annual disposable income of a household increases and the social aspect of taxation is highlighted. These are:

- Tax relief on social security contributions made on retirement, which is reflected in a reduction of annual tax bases with compulsory contributions, made to purchase pension rights at retirement (Personal Income Tax Act, Art. 20, para. 23, item 2, Art. 28, para. 2, item 3, Art. 49, para. 3, item 2 and para. 4, item 3 Social Security Code, Art. 9a).

- Tax relief on donations. There is an opportunity that the annual tax bases on individuals' income from employment, business, rent, and transfer of rights or property and from other sources are reduced by the amount of the donation depending on the institution or organisation to whose benefit it is.

- Tax relief for persons with 50 or over 50 per cent reduced working capacity, resulting in a reduction of the annual tax bases with the amount of BGN 7920 or in advance withholding tax - with BGN 660 on a monthly basis.

- Tax relief for personal contributions made for additional voluntary social security (up to $10 \%$ of annual tax bases of the individual), voluntary health insurance and "life" insurance (up to $10 \%$ for cost of the annual tax bases of the individual).

- Tax relief for young families, according to which from the annual tax bases interest payments on the first BGN 100000 are deduced for a mortgage credit to purchase the housing, where the following requirements are met: the mortgage credit contract is signed by a taxable person and/or spouse in civil marriage; the taxable person and/or spouse is more than 35 years of age at the date of signing the mortgage credit contract; the mortgaged housing is the only housing of the family during the tax year.

\section{CONCLUSION}

Households form income from different directions, and in accordance with the regulations of our country households' income should be declared and fiscal obligations should be repaid (Radilov, 2016, pp. 3-19). Provided in the Bulgarian tax system preferences primarily pursue: social effects, resulting in increased disposable income of taxpayers, including households that bring up minor children; promotion of savings; investment and charity activity. In this sense, in view of existing opportunities for reduction of tax liabilities of individuals, knowing the peculiarities of taxation relating to the formation of their disposable income (and the income of households to which they belong) is defined as a prerequisite for the effective management of personal finances and significant aspect of personal financial management. 


\section{REFERENCES}

Angelov, A. \& Radulova, A. (2011). Personal finances - basic unit of financial system. The Scientific Research almanac, Svishtov: Tsenov Publishing House, 14, 43-83.

Brusarski, R., Zahariev, A. \& Manliev, G. (2015). Finance Theory, Faber, V. Tarnovo, 79-89.

Boskin, M. J. (1978). Taxation, Saving and the Rate of Interest. Journal of Political Economy, 86(2), 3-27. http://dx.doi.org/10.1086/260692

Callaghan, G. \& Fribbance, I. (2007). Personal Finance, Palgrave Macmillan, 47-87.

Dimitrova, T. (2010). Personal Finances. Svishtov: Tsenov Publishing House, $70-85$.

Dimitrova, T. (2012). Households in Bulgaria - financial category and relations, Svishtov: Narodnostopanski archiv, (3), 20-38.

Kapoor, J., Dlabay, Les, R. \& Hughes, R. (2009). Personal Finance. McGraw-Hill Irwin, 83.

King, J. \& Carey, M. (2014). Personal Finance: A Practical Approach. Oxford University Press, 15-24.

Local Taxes and Fees Act. (2015).

Law on State Social Insurance. (2015).

Pavlova, M. (2014). Tax Policy of the Republic of Bulgaria for the Period 2007-2013. Економічний вісник Донбасу, 4(38), 115-120. Retrieved from http://dspace.nbuv.gov.ua/xmlui/bitstream/handle/123456789/ 87631/17-Pavlova.pdf?sequence $=1$

Personal Income Tax Act. (2015).

Radilov, D. \& Chervenski, G. (2016). VAR - models of shocks in the business cycles of final consumption expenditure of households, Svishtov: Nrodnostopanski archiv, 2, 3-19.

Radulova, A. (2015). Personal finances. Faber, V. Tarnovo, 20-25.
Radulova, A. (2011). Personal Finances in Bulgaria - theoretical aspects and empirical evidence, Tsenov Publishing House, Library "Education and Sciense," 1, 59-64.

Rosefsky, R. S. (1999). Personal Finance (7th ed.). John Wiley and Sons Inc., 617-636.

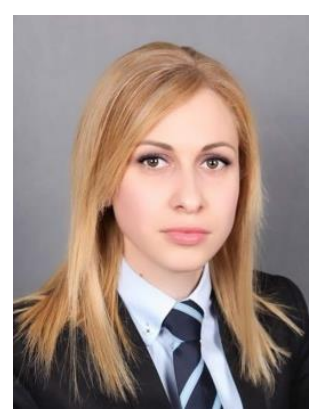

Mariyana Pavlova, $\mathrm{PhD}$, has been an Assistant at the Department of Finance and Credit at Tsenov Academy of Economics, Svishtov, Bulgaria since 2014. From 2012 to 2015 she was a PhD student at the same department and in March 2015 earned PhD degree. Before that she was the Bachelor student (2006-2010), specialty "Finance", and Master student (2010-2011) at the program "Financial Management".

Before starting $\mathrm{PhD}$ studies, she worked at the largest commercial bank in Bulgaria for a couple of months. After that all of her efforts have been focused on scientific research and earning of $\mathrm{PhD}$ degree. The main research interests are related to the field of personal finance, taxation and budget policy. Some of her scientific studies are:

- Tax Policy of the Republic of Bulgaria for the Period of 2007-2013, Ukraine, 2014,

- Financial strategies and investment activity of Bulgarian households, Bulgaria, 2014,

- The good practices in Estonia embark on its way to economic and financial union, Bulgaria, 2015. 